\title{
ANALISIS TINDAK TUTUR ANTARA PENJUAL DAN PEMBELI DI PASAR SUMBERAYU MUNCAR BANYUWANGI ( KAJIAN PRAGMATIK ) TAHUN 2020
}

\author{
M. Hasbullah Ridwan, M.Pd \\ Muhammad Abu Riza
}

\author{
IAI Darussalam Blokagung Banyuwangi \\ hasbullahridwan@iaida.ac.id \\ aburiza647@gmail.com
}

\begin{abstract}
ABSTRAK
Tindak tutur merupakan tindakan-tindakan yang ditampilkan lewat tuturan. Artinya hal seperti itu mengandung sebuah asumsi bahwa tuturan-tuturan yang kita ucapkan sejatinya bukanlah sebuah tuturan-tuturan kosong tanpa adanya sebuah kandungan tindakan di dalamnya, ataupun kosong dari konteks yang sedang terjadi. Tindak tutur terbagi menjadi tiga jenis, yakni tindak tutur lokusi, ilokusi dan perlokusi. Problematika yang dibahas dalam penelitian ini, adalah 1) Bagaimanakah bentuk-bentuk tindak tutur antara penjual dan pembeli di Pasar Sumberayu Muncar Banyuwangi?. 2) Masuk dalam kategori tindak tutur apakah tuturan yang diucapkan oleh penjual dan pembeli di Pasar Sumberayu Muncar Banyuwangi.Penelitian ini bertujuan untuk mengetahui bentuk-bentuk tindak tutur antara penjual dengan pembeli di Pasar Sumberayu Muncar Banyuwangi, serta untuk mengetahui maksud yang terkandung dalam bentuk-bentuk tindak tutur dan termasuk kategori tindak tutur apakah tuturan yang diucapkan oleh penjual dengan pembeli di Pasar Sumberayu Muncar Banyuwangi.Peneliti di sini menggunakan pendekatan kualitatif. Pendekatan kualitatif adalah suatu pendekatan yang berdasarkan pada latar alamiah atau naturalis. Teknik pengumpulan data penelitian menggunakan teknik simak dan teknik catat, teknik analisis data metode analisis mengalir yang meliputi reduksi data, penyajian data dan penarikan kesimpulan/verivikasi. Hasil penelitian adalah tindak tutur yang terdiri dari 19 bentuk percakapan yang terdiri 86 tindak tutur lokusi, 20 tindak tutur ilokusi, dan 14 tindak tutur perlokusi yang dituturkan antara penjual dan pembeli yang terdiri mulai dari penjual sayuran, penjual buah-bauhan, penjual nasi ampok, penjual jajanan tradisional, penjual kedelai dan lain-lain.
\end{abstract}

Kata Kunci: Tindak Tutur, Penjual dan Pembeli 


\begin{abstract}
Speech acts are actions that are displayed through speech. This means that something like that contains an assumption that the utterances we speak are not really empty speeches without any action content in them, or empty of the current context. Speech acts are divided into three types, namely speech acts of locus, illocution and perlocution. The problems discussed in this research are 1) What are the forms of speech acts between the seller and the buyer at Sumberayu Market, Muncar Banyuwangi? 2) It is included in the category of speech acts whether the utterances uttered by sellers and buyers at Sumberayu Muncar Banyuwangi Market. This study aims to determine the forms of speech acts between sellers and buyers at Sumberayu Muncar Banyuwangi Market, and to find out the meaning contained in the the form of speech acts and including the category of speech acts whether the utterances spoken by the seller and the buyer at Sumberayu Market Muncar Banyuwangi. Researchers here use a qualitative approach. A qualitative approach is an approach based on a natural or naturalist background. Research data collection techniques using observation techniques and note-taking techniques, data analysis techniques flow analysis methods which include data reduction, data presentation and drawing conclusions / verification. The results of the study were speech acts which consisted of 19 forms of conversation consisting of 86 locusive speech acts, 20 illocutionary speech acts, and 14 perlocutionary speech acts which were spoken between sellers and buyers consisting of vegetable sellers, fruit-fruit sellers, ampok rice sellers, traditional hawker sellers, soybean sellers and others.
\end{abstract}

Keywords: Speech Actions, Sellers and Buyers

\title{
A. Pendahuluan
}

Bahasa memegang peranan pentingdalam kehidupan manusia. Bahasa sebagai alat berinteraksi dan berkomunikasi dengan manusia lain. Bahasa adalah suatu kenyataan bahwa manusia mempergunakan bahasa sebagai alat vital dalam kehidupan sehari-hari. Bahasa adalah alat untukberkomunikasi yangdapat digunakan untuk bertukar pendapat, berdiskusi, atau membahas persoalan yang dihadapi. Menurut Keraf (1994: 1) Bahasa ialah alat komunikasi antar anggota masyarakat berupa simbol bunyi yang dihasilkan oleh alat ucap manusia. Sedangkan menurut Tarigan (2015: 8) mengemukakan bahwa komunikasi mempersatukan individu ke dalam kelompok-kelompok dengan jalan menggolongkan konsep-konsep umum. Selain itu, menciptakan dan mengawetkan ikatan-ikatan kepentingan umum, menciptakan kesatuan lambang-lambang yang membedakannya dengan kelompok lain. 
Komunikasi secara lisan sebagai pertukaran informasi melalui penggunaan lambang-lambang verbal dan non verbal, mode-mode, serta proses-proses produksi dalam berbahasa. Penggunaan lambang-lambang verbal dan non verbal yang ditemui dalam bahasa lisan yang digunakan oleh seseorang saat berbicara sering ditanggapi secara berbeda oleh partisipan atau lawan bicara. Pragmatik adalah studi tentang makna dalam hubungannya dengan situasi-situasi ujar. Menurut Yule (2014: 5) Pragmatik adalah studi tentang hubungan antara bentuk-bentuk linguistik dan pemakai bentuk-bentuk itu. Jadi, dapat dikatakan bahwa, pragmatik merupakan cabang dari linguistik atau bahasa yang mengkaji makna tuturan dengan cara menghubungkan faktor non lingual seperti konteks, pengetahuan, komunikasi, serta situasi pemakaian bahasa dalam rangka penggunaan tuturan oleh penutur dan lawan tutur. Makna tuturan dalam pragmatik lebih mengacu pada maksud dan tujuan penutur terhadap tuturannya.

Untuk mudahdipahami oleh partisipan, pembicara memerlukan tindak tutur atau pertuturan secara teratur. Yule (2014: 82-83) mengemukakan tindak tutur adalah suatu tindakan-tindakan yang ditampilkan lewat tuturan dan dalam bahasa Inggris secara umum diberi label yang lebih khusus, misalnya permintaan maaf, keluhan, pujian, undangan, janji atau permohonan. Peristiwa tutur merupakan gejala sosial, sedangkan tindak tutur merupakan gejala individual, dan berlangsungnya ditentukan oleh kemampuan berbahasa penutur dalam menghadapi situasi tertentu. Peristiwa tutur banyak dilihat pada makna/arti tindakan dalam tuturannya. Tindak tutur dan peristiwa tutur adalah dua gejala yang terjadi pada suatu proses yaitu proses komunikasi (Chaer dan Agustina, 1995: 61).

Pasar tradisionalSumberayu merupakan pasar tradisional yang terletak di Dusun Sumberayu Desa Sumberberas Kecamatan Muncar Kabupaten Banyuwangi Propinsi Jawa Timur. Keberadaan Pasar Tradisional Sumberayu ini sangat membantu, tidak hanya bagi pemerintah daerah ataupun pusat tetapi juga bagi para masyarakat yang menggantungkan hidupnya dalam kegiatan berdagang, karena di dalam Pasar tradisional Sumberayu terdapat banyak orang yang memiliki kepentingan dan berusaha untuk menyejahterakan kehidupannya baik itu pedagang, pembeli, pekerja panggul dan sebagainya. 
Data yang diperoleh peneliti sebagian besar bahasa yang dipakai untuk kegiatan transaksi di pasar tersebut berupa bahasa jawa. Hal tersebut disebabkan mayoritas pengunjung di Pasar tradisional sumberayu adalah orang-orang asli suku jawa dan pengguna bahasa jawa asli. Hanya sedikit data yang menunjukkan penggunakanbahasa Indonesia selama proses transaksi jual beli berlangsung.

Peneliti memilih tindak tutur penjual dan pembeli di pasar tradisional Sumberayu sebagai objek penelitian. Penelitian ini dilakukan selama bulan April sampai dengan Juli 2020. Pasar tradisional Sumberayu juga tidak hanya sekedar pasar pada umumnya tetapi juga sudah menjadi pasar yang pengunjungnya tidak hanya dari daerah Sumberayu saja tetapi ada yang dari daerah sekitar bahkan dari luar kecamatan. Salah satu alasan pasar tradisional Sumberayu dijadikan lokasi penelitian adalah belum pernah ada yang melakukan penelitian tindak tutur di pasar tradisional Sumberayu sebagai bahan skripsi.

Peneliti tertarik mengkaji dan meginterpretasi tindak tutur yang ada dalam pasar tersebut karena menurut peneliti, ketika ada banyak sekali orang yang melakukan transaksi jual-beli maka di situ juga akan ada banyak sekali pembicaraan yang menurut peneliti sangat menarik untuk dianalisis terutama yang berkaitan dengan tindak tutur, baik itu berkenaan dengan cara menawarkan barang dagangan, menawar untuk mendapatkan harga terendah, maupun sekedar percakapan basabasi penjual kepada para pembeli agar barang dagangannya bisa laku terjual.

Sebagaimana yang sudah diketahui sebelumnya bahwa, tindak tutur itu terbagi menjadi tiga jenis, yakni lokusi, ilokusi dan perlokusi. Contoh dialog penjual dan pembeli yang pernah peneliti temui ketika melakukan berada di dalam pasar, (1a) Penjual : "Yu Jum, kok ra kenal aku tho ?" (Mbak Jum, kok tidak kenal saya ?) (1b) Pembeli : “Ora, ora kenal aku”. (Tidak, tidak kenal saya). Tuturan (1a) "Yu Jum, kok ra kenal aku tho ?" merupakan bentuk tindak tutur ilokusi karena dalam tuturan tersebut penutur mengungkapkan secara tidak langsung maksud dan tujuan yang diharapkan. Penutur menyindir secara halus kepada pembeli dengan tujuan agar pembeli tersebut mau berhenti dan mau melirik dagangannya dan akhirnya membelinya. Tuturan (1b) “Ora, ora kenal aku” merupakan bentuk tindak 
tutur lokusi yakni hanya sebatas ungkapan bahwa ia tidak mau berhenti dan melirik barang dagangan si penjual karena mungkin saja ia belum berminat membelinya.

Berdasarkan latar belakang di atas, peneliti tertarik untuk melakukan penelitian yang berjudul "Analisis Tindak Tutur antara Penjual dengan Pembeli di Pasar Sumberayu Muncar Banyuwangi: Kajian Pragmatik.",

\section{B. Landasan Teori}

\section{A. Pengertian Tindak Tutur}

Menurut Yule ( 2014:82 ) tindak tutur merupakan tindakan-tindakan yang ditampilkan lewat tuturan. Artinya sebagaimana yang sudah dikemukakan oleh ahli bahasa tersebut, pendapat seperti itu mengandung sebuah asumsi bahwa tuturantuturan yang kita ucapkan sejatinya bukanlah sebuah tuturan-tuturan kosong tanpa adanya sebuah kandungan tindakan di dalamnya ataupun kosong dari konteks yang sedang terjadi. Tarigan ( 2009: 16 ) menyatakan bahwa tindak tutur merupakan gejala individual, bersifat psikologis dan keberlangsungannya ditentukan oleh kemampuan bahasa si penutur dalam menghadapi situasi tertentu dan dilihat pada makna atau arti tindakan dalam tuturannya. Artinya, dengan kata lain, kedua belah pihak, yaitu penutur dan petutur terlibat dalam suatu tujuan kegiatan yang berorientasi pada tujuan tertentu.

Sejalan dengan pendapat Yule tersebut, Searle (dalam Wijana, 2009:20) memberikan pengertian bahwa tindak tutur adalah hasil dari suatu kalimat dalam kondisi tertentu dan merupakan satuan terkecil dari komunikasi bahasa. Dilihat dari sudut pandang ini, memang tindak tutur haruslah menyertakan konteks yang sedang terjadi saat itu, artinya dalam kajian tindak tutur tersebut, kita tidak akan mampu mengungkap makna yang terkandung secara tepat kalau kita menafikan terhadap konteks yang sedang terjadi, jadi pada intinya, konteks tuturan itu merupakan hal yang sangat penting sekali mengingat hal tersebut juga menjadi kunci keberhasilan dalam melakukan sebuah proses komunikasi yang nyaman, baik dan interaktif.

Lebih jauh lagi, Chaer (2010: 39) berpendapat bahwa faktor yang menyebabkan satu proses komunikasi menjadi gagal biasanya datang dari lawan tutur, antara lain (a) lawan tutur tidak mempunyai pengetahuan yang dibicarakan, (b) lawan tutur dalam keadaan tidak sadar atau tidak fokus, (c) lawan tutur tidak 
tertarik dengan topik yang dituturkan, (d) lawan tutur tidak berkenan dengan cara penutur menyampaikan informasi, (e) lawan tutur tidak mempunyai apa yang diinginkan penutur, dan (f) lawan tutur tidak memahami apa yang dimaksud oleh penutur.

\section{B. Macam-Macam Tindak Tutur}

Searle dalam bukunya yang berjudul Act: An Essay in the Philoshopy of Languagepernah mengemukakan bahwa secara pragmatis ada tiga jenis tindakan yang dapat diwujudkan oleh seorang penutur yaitu tindak lokusi (locutionary act), tindak ilokusi (illocutionary act), dan tindak tutur perlokusi (perlocutionary act). Sedangkan kata Chaer (2010: 83) lebih lanjut lagi menjelaskan bahwa tindak tutur dalam kajian ilmu pragmatik terdapat tiga, yaitu tindak tutur lokusi, ilokusi, dan perlokusi. Pertama adalah tindak lokusi, yang merupakan tindak dasar tuturan atau menghasilkan suatu ungkapan linguistik yang bermakna. Kedua tindak tutur ilokusi ditampilkan melalui penekanan komunikatif suatu tuturan.

Menuturkan untuk membuat suatu pernyataan, tawaran, penjelasan, atau maksud-maksud komunikatif lainnya. Ketiga tindak perlokusi yakni menuturkan dengan asumsi bahwa pendengar akan mengenali akibat yang ditimbulkan. Hal tersebut senada dengan pendapat seorang ahli bahasa generasi awal yakni Austin yang juga membagi jenis tindak tutur menjadi lokusi, ilokusi, dan perlokusi. Berkenaan dengan tuturan tersebut, lebih lanjut, ia mengemukakan pandangannya tersebut yakni: (1) tindak tutur lokusi, yaitu tindak mengucapkan sesuatu dengan kata dan kalimat sesuai dengan makna di dalam kamus dan menurut kaidah sintaksisnya, (2) tindak tutur ilokusi, yaitu tindak tutur yang mengandung maksud, berkaitan dengan siapa bertutur kepada siapa, kapan, dan dimana tindak tutur itu dilakukan, dan (3) tindak tutur perlokusi, yaitu tindak tutur yang pengujarannya dimaksudkan untuk mempengaruhi mitra tutur. lebih jauh lagi seperti yang telah diungkapkan oleh Yule (2014: 83) yakni, “pada suatu saat tindakan yang ditampilkan dengan menghasilkan suatu tuturan akan mengandung tiga tindak yang saling berhubungan. Yang pertama adalah lokusi, yang merupakan tindak dasar tuturan atau menghasilkan suatu ungkapan linguistik yang bermakna..., kita membentuk tuturan dengan beberapa fungsi di dalam fikiran. Ini adalah dimensi 
kedua, atau tindak ilokusi. Tindak ilokusi ditampilkan melalui penekanan komunikasi suatu tuturan ..., tentu kita tidak secara sederhana menciptakan tuturan yang memiliki fungsi tanpa memaksudkan tuturan itu memiliki akibat. Inilah dimensi ke tiga, tindak perlokusi”.

Melihat adanya kesesuaian pendapat beberapa ahli bahasa terkemuka tersebut maka, pembagian jenis tindak tutur adalah sebagai berikut, seperti yang pernah dikemukakan oleh Austin (dalam Sulistyo, 2013: 6-7).

\section{Tindak Tutur Lokusi (locution)}

Tindak tutur lokusi (locution) adalah tuturan yang disampaikan kepada mitra tutur atau tindak tutur yang mengacu ke tindakan mengucapkan tuturan yang secara semantis mempunyai makna. Contoh tuturan locution adalah "Saya sedih". Kalimat tersebut jika disampaikan kepada teman senasib meskipun tidak dijelaskan secara detail, mereka akan menyadari karena rasa sedih tersebut disebabkan oleh persamaan nasib yang menimpa mereka seperti contoh studinya yang bertahuntahun belum lulus.

Dalam pengertian lain seperti yang pernah diungkapkan oleh salah seorang pakar yakni Gunarwan yang mengatakan bahwa tindak tutur lokusi adalah tindak tutur yang dimaksudkan untuk menyatakan sesuatu, tindak mengucapkan sesuatu dengan kata dan makna kalimat sesuai dengan makna kata itu di dalam kamus dan makna kalimat itu menurut kaidah sintaksisnya. Fokus lokusi adalah makna tuturan yang diucapkan oleh penuturnya, bukan mempermasalahkan maksud atau fungsi tuturan itu. Rahardi (2003: 71) mendefinisikan bahwa lokusi adalah tindak bertutur dengan kata, frasa, dan kalimat sesuai dengan makna yang dikandung oleh kata, frasa, dan kalimat itu.

Lokusi dapat dikatakan sebagai the act of saying something. Tindak lokusi merupakan tindakan yang paling mudah diidentifikasi karena dalam pengidentifikasiannya tidak memperhitungkan konteks tuturan (Rohmadi, 2004:

30). Contoh tindak tutur lokusi adalah ketika seseorang berkata " badan saya lelah sekali ". Penutur tuturan ini tidak merujuk kepada maksud tertentu kepada mitra tutur. Tuturan ini murni bermakna bahwa si penutur sedang dalam keadaan lelah 
yang teramat sangat, tanpa bermaksud meminta untuk diperhatikan dengan cara misalnya dipijit ataupun dikerokin oleh si mitra tutur.

Penutur hanya mengungkapkan keadaannya yang tengah dialami saat itu. Contoh lain misalnya kalimat " Sandy bermain gitar ". Kalimat ini dituturkan semata-mata untuk menginformasikan sesuatu tanpa tendensi untuk melakukan sesuatu apalagi untuk mempengaruhi lawan tuturnya. Tindak lokusi adalah tindak menuturkan sesuatu. Sang pakar yakni Austin pernah menyatakan bahwa lokusi hanyalah menuturkan sesuatu, menyampaikan informasi, berbicara, dan lain-lain. Tuturan lokusi patuh pada kondisi kebenaran dan membutuhkan akal/rasa dan referensi agar dapat dimengerti, referensi tergantung pada pengetahuan pembicara pada saat penuturan. Seoarang pakar lain bernama Sadock menyebut tindak lokusi sebagai "tindak yang dilakukan untuk berkomunikasi", sedangkan menurut Habermas bahwa lokusi adalah tindak menyatakan keadaan sesuatu. Pada intinya dapat dikatakan bahwa mengatakan sesuatu adalah melakukan tindak lokusi.

\section{Tindak Tutur Ilokusi (Ilocution)}

Tindak tutur ilokusi merupakan tuturan apa yang ingin disampaikan kepada mitra tutur (petutur) atau tindak tutur yang mengacu ke tindakan mengucapkan tuturan yang disamping mempunyai makna semantis juga mempunyai daya tuturan atau maksud tuturan (di dalam arti untuk apa tuturan itu diungkapkan dan disampaikan). Contoh tindak ilokusi yaitu "Jalan berlubang". Arti yang ingin disampaikan dalam kalimat itu ialah, bukan hanya sebagai informasi bahwa ada jalan yang berlubang, namun lebih dari itu, kalimat tersebut juga memberikan makna tersirat yakni, agar pengendara yang lewat di jalan itu selalu berhati-hati dan waspada. Pragmatik menganggap bahasa dalam tingkatan yang lebih konkret daripada tata bahasa. Singkatnya ialah, ucapan dianggap sebagai suatu bentuk kegiatan suatu tindak ujar .

Menurut pendapat Austin (Rustono, 1999: 37) ilokusi adalah tindak melakukan sesuatu. Ilokusi merupakan tindak tutur yang mengandung maksud dan fungsi atau daya tuturan. Pertanyaan yang diajukan berkenaan dengan tindak ilokusi lebih jauh lagi levelnya dibandingkan dengan tindak tutur lokusi yakni "untuk apa ujaran itu dilakukan” dan sudah bukan lagi dalam tataran "apa makna tuturan itu?”. 
Sedangkan Rohmadi (2004: 31) mengungkapkan bahwa tindak ilokusi adalah tindak tutur yang berfungsi untuk mengatakan atau menginformasikan sesuatu dan dipergunakan untuk melakukan sesuatu. Contoh tindak tutur ilokusi adalah "udara panas". Tuturan ini mengandung maksud bahwa si penutur meminta agar pintu atau jendela segera dibuka, atau meminta kepada mitra tutur untuk menghidupkan kipas angin. Jadi jelas bahwa tuturan itu mengandung maksud tertentu yang ditujukan kepada mitra tutur. Contoh lain, kalimat "Suseno sedang sakit". Jika kalimat ini dituturkan kepada mitra tutur yang sedang menyalakan televisi dengan volume yang sangat tinggi, berarti tuturan ini tidak hanya dimaksudkan untuk memberikan informasi, tetapi juga menyuruh agar mengecilkan volume atau bahkan mematikan televisi agar Suseno bisa beristirahat dengan tenang.

Diantara ketiga jenis tindak tutur, yang dominan menjadi kajian ilmu pragmatik adalah tindak tutur ilokusi. Inti dari tindak tutur dan sekaligus kajian tuturan performatif seperti yang dinyatakan oleh Austin adalah ilokusi yang terkandung dalam sebuah tuturan. Austin membagi jenis tindak ilokusi menjadi lima kategori, yakni:

1. Verdiktif (verdictive) adalah tindak ilokusi yang merupakan penyampaian hasil penilaian atau keputusan berdasarkan alasan ataupun fakta tertentu. Contoh tindak ini adalah menilai, mendiagnosis, mengkalkulasi, meramalkan, dan lain-lain;

2. Eksersitif (excercitives) di dalam tindak ini penutur menggunakan kekuatan, hak atau pengaruhnya, misalnya menyuruh, mendoakan, merekomendasikan, dan lain-lain;

3. Komisif (commissives), yakni tindak pembicara berkomitmen untuk sebab atau tindakan, misalnya janji dan pertaruhan;

4. Behabitif (behabitives), yakni ekspresi reaksi penutur terhadap sikap dan perilaku orang, baik masa lalu, masa kini atau masa depan. Sebagai contoh adalah maaf, terima kasih, selamat, dan lain-lain.

5. Ekspositif (expositives) yakni tindakan eksposisi yang melibatkan penjabaran pandangan, pelaksanaan argumen, dan klarifikasi penggunaan dan referensi. Penutur menjelaskan bagaimana ucapan 
mereka sesuai dengan alur penalaran, misalnya, mendalilkan dan mendefinisikan, menyetujui, dan lain-lain.

Kategorisasi Austin kemudian dikembangkan oleh muridnya, Searle dangan alasan bahwa disusun hanya berdasarkan leksikografis dan batasan-batasan diantara kelima kategorisasi tersebut kurang jelas dan timpang tindih. Padahal batasannya harus jelas agar mempermudah orang dalam mengidentifikasi tindak ilokusi. Searle kemudian membuat kategorisasi baru yang juga berjumlah lima.

1. Asertif, yakni tuturan yang mengikat penutur pada kebenaran proposisi yang diungkapkan, misalnya menyatakan, menyarankan, membual, mengeluh, dan mengklaim.

2. Direktif, tuturan yang dimaksudkan agar si mitra tutur melakukan tindakan sesuai tuturan, misalnya, memesan, memerintah, memohon, menasihati, dan merekomendasi.

3. Komisif, yakni tindak yang menuntut penuturnya berkomitmen melakukan sesuatu di masa depan. Contohnya adalah berjanji, bersumpah, menolak, mengancam, dan menjamin.

4. Ekspresif, yakni ungkapan sikap dan perasaan tentang suatu keadaan atau reaksi terhadap sikap dan perbuatan orang. Contoh memberi selamat, bersyukur, menyesalkan, meminta maaf, menyambut, dan berterima kasih.

5. Deklaratif, yakni ilokusi yang menyebabkan perubahan atau kesesuaian antara proposisi dan realitas. Contohnya adalah membaptis, memecat, memberi nama, dan menghukum.

Dari kategorisasi yang dibuat oleh Searle, dapat disimpulkan bahwa sebenarnya semua tuturan adalah performatif atau sebuah tindak tutur. Oleh karena itu Searle menyarankan bahwa unit dasar komunikasi linguistik adalah tindak tutur. Ini bisa berupa kata, frasa, kalimat atau suara, yang mempunyai makna mengekspresikan niat pengguna. Sehingga dapat dikatakan bahwa tindak tutur adalah satuan bahasa dalam pragmatik, seperti halnya morfem, kata, frasa, dan kalimat sebagai satuan bahasa dalam linguistik. Jenis satuan tindak tutur dapat beragam dari suara tertentu, kata, frasa, kalimat, dan bahkan sampai dengan wacana. 
Dalam arti, selama bunyi itu dimaksudkan untuk makna tertentu, dapat dikatakan sebagai tindak tutur.

\section{Tindak Tutur Perlokusi (Perlocution)}

Tindak tutur perlokusi (Perlocution) yaitu pesan yang harus diinterpretasikan oleh mitra tutur atau dengan istilah lain bahwa tuturan ini mengacu ke tindakan mengucapkan tuturan di samping mempunyai makna (semantis), dan mempunyai daya (yang bertumpu pada maksud tuturan), juga mempunyai efek kepada si mitra tutur. Menurut Austin tindak perlokusi adalah apa yang kita hasilkan atau capai dengan mengatakan sesuatu seperti meyakinkan, membujuk, menghalangi, mengatakan, mengejutkan atau menyesatkan. Tindak perlokusi dengan demikian harus dipahami sebagai hubungan sebab akibat antara dua peristiwa, penyebabnya adalah produksi tuturan oleh penutur.

Perlokusi harus dibedakan dengan lokusi dan terutama dengan ilokusi. Perlokusi adalah efek atau dampak dari tuturan (lokusi) yang dituturkan, yang di dalamnya mengandung maksud tertentu (ilokusi). Tindak perlokusi lebih bersifat alami, tidak diatur oleh konvensi dan tidak dapat dikonfirmasi dengan pertanyaan. Contoh sederhana tindak perlokusi yakni “ Tahun depan masa studimu sudah berakhir ". Tuturan ini jika disampaikan kepada mahasiwa yang benar-benar sudah pada tahun akhir tersebut akan memiliki daya pengaruh terhadap mahasiswanya. Hal ini juga berdampak kepada mahasiswa menjadi ketakutan jika dirinya dikenakan sangsi dikeluarkan (drop out), Tuturan yang diucapkan penutur sering memiliki efek atau daya pengaruh (perlocutionary force). Efek yang dihasilkan dengan mengujarkan sesuatu itulah yang oleh sang ahli tersebut dinamakan perlokusi, yang mana efek atau daya tuturan itu dapat ditimbulkan oleh penutur secara segaja, dapat pula secara tidak sengaja.

Tindak tutur yang pengujaran dimaksudkan untuk memengaruhi mitra tutur inilah merupakan tindak perlokusi. Beberapa verba itu antara lain membujuk, menipu, mendorong, membuat jengkel, menakut-nakuti, menyenangkan, mempermalukan, menarik perhatian, dan lain sebagainya Contoh tuturan yang merupakan tindak perlokusi adalah kata-kata seperti: ada hantu!, sikat saja!, dia selamat, Bu. Tiga kalimat tersebut masing-masing memiliki daya pengaruh yaitu 
menakut-nakuti, mendorong, dan melegakan. Tindak perlokusi, yakni membujuk, menghasut, marah, dan lain-lain menghasilkan perubahan fisiologis pada mitra tuturnya (pendengarnya), menghasilkan efek psikologis, sikap, maupun perilaku.

Ringkasnya ketiga tindak ini dapat dibedakan dengan pernyataan "seorang penutur mengucapkan kalimat dengan makna tertentu (tindak lokusi), dan dengan kekuatan tertentu (tindak ilokusi), untuk mencapai efek tertentu pada pendengar (tindak perlokusi). Contoh lain, ketika seorang pria mengatakan kepada gadis tunangannya, "Aku akan menikahimu setelah lebaran tahun ini” Tindak lokusinya adalah "Aku akan menikahimu setelah lebaran tahun ini”, tindak ilokusinya adalah sebuah janji, dan tindak perlokusinya meyakinkan gadis tunangannya dengan adanya janji yang terkandung dalam tuturan tersebut.

\section{Teori Tentang Pengertian Penjual dan Pembeli}

\section{a. Pengertian Penjual dan Penjualan}

Penjual adalah orang yang melakukan sebuah akifitas pemasaran yang ditujukan untuk menyampaikan barang kepada konsumen yang berasal dari produsen. Upaya ini dilakukan untuk menghubungkan sekaligus memberikan keuntungan antara pihak konsumen dan pihak produsen, yakni konsumen akan bisa memenuhi kebutuhannya dan produsen bisa memperoleh keuntungan dari hasil penjualannya. Beberapa kegiatan yang dilakukan oleh penjual seperti mencari pembeli, memengaruhi pembeli, serta memberi arahan agar pembeli bisa menyesuaikan kebutuhannya dengan produk yang ditawarkan dengan ikatan perjanjian harga yang menguntungkan kedua belah pihak. Sebenarnya kalau mau kita telaah lebih mendalam, aktifitas yang dilakukan oleh penjual yakni menjual terhadap beberapa atau satu jenis produk tertentu produk yang ia jual, sejatinya bukanlah untuk memenuhi kebutuhan para konsumen semata, namun esensi dari ini adalah untuk memenuhi kebutuhan individu maupun kebutuhan lain yang menjadi tanggung jawab dari sang penjual tersebut.

Sedangkan pengertian Penjualan adalah bagian dari kegiatan pemasaran yang memiliki makna yang luas yang meliputi berbagai fungsi perusahaan. Pemasaran adalah sistem keseluruhan dari kegiatan usaha yang ditujukan untuk merencanakan, menentukan harga, mempromosikan untuk dapat dipasarkan (Mega, 2013:1). 
Sedangkan menurut Hayuningtyas (2015:161) pengertian penjualan adalah proses akhir dari kegiatan pemasaran, karena pada proses ini ada penetapan harga, serah terima barang dan adanya pembayaran yang disepakati oleh penjual dan pembeli.

Dari pengertian di atas, peneliti menyimpulkan bahwa penjualan adalah sebuah proses dimana seseorang yakni penjual melakukan kegiatan pemasaran untuk memperoleh pendapatan dan laba terhadap produk yang ia pasarkan guna memenuhi kebutuhan yang dibutuhkan dan diinginkan oleh pembeli. Bentukbentuk penjualan yang dilakukan oleh penjual ini bisa dikelompokkan menjadi penjualan tunai, penjualan kredit, penjualan tender, penjualan ekspor dan penjualan titipan. Secara keseluruhan, dari penjualan ini dipengaruhi oleh kondisi atau daya beli pasar yang terjadi saat itu. Hal ini disebabkan oleh faktor seperti barang yang tersedia, harga yang ditawarkan, syarat penjualan, dll. Sedangkan dari segi penjualan juga tak terlepas dari modal si penjual. Modal tersebut berupa kemampuan untuk lebih mengenalkan produk yang sedang ia jual agar nantinya ia bisa mempunyai pasaran yang lebih luas lagi.

Lebih lanjut lagi menurut (Parise, dkk, 2016) menunjukkan bahwa penjual harus mampu menjelaskan produk yang ditawarkannya dengan baik dan interaktif, untuk dapat membuat konsumen merasa tidak terpaksa, "nyambung" dengan yang ditawarkan penjual dan merasa sesuai dengan yang dibutuhkan secara kognitif dan emosional. Tentu saja hal seperti ini akan terjadi apabila ada interaksi yang baik dan nyaman antara penjual dan pembeli. Interaksi sosial yang baik sangatlah berperan penting dalam pengambilan keputusan pembeli untuk membeli suatu barang ( closing ).

Selanjutnya (Catalin dan Laurentiu, 2014) berpendapat bahwa terdapat dua faktor yang memengaruhi konsumen dalam membeli produk yang sedang ditawarkan yaitu faktor intrinsik atau faktor yang berasal dari diri sendiri dan juga faktor ekstrinsik yang berasal dari luar diri sendiri/lingkungan seperti rekomendasi dari teman ataupun kolega.

\section{b. Pengertian Pembeli dan Pembelian}

Kata pembeli berasal dari Bahasa Inggris, yakni consumer, yang menurut KBBI diartikan sebagai seseorang atau sesuatu perusahaan yang membeli barang 
tertentu atau menggunakan jasa tertentu, atau seseorang yang mengunakan suatu persediaan atau sejumlah barang. Artinya dari istilah ini pembeli itu tidak hanya tertentu pada orang maupun perorangan saja, namun juga mencangkup dari sebuah perusahaan maupun suatu badan usaha tertentu. Ada juga yang mengartikan pembeli sebagai setiap orang yang menggunakan barang atau jasa.

Pembeli adalah orang yang melakukan sebuah bentuk usaha untuk memenuhi kebutuhan dan mendapatkan barang/jasa. Nilai manfaat yang terkandung dalam barang ataupun jasa tersebut akan dinikmati oleh pembeli itu sendiri. Bentukbentuk pembelian berdasarkan pembayarannya juga hampir sama dengan penjualan, karena dua proses ini terjadi dalam satu waktu dan satu kesepakatan, maka pembelian ini bisa saja dilakukan secara tunai ataupun pembayaran secara kredit atau tempo.

Sedangkan pengertian dari pembelian sendiri adalah transaksi belanja untuk barang masuk atau pengeluaran uang yang kita lakukan untuk mendapatkan produk yang akan dijual, transaksi ini terjadi pada supplier yang produknya dibeli ( Nugroho, 2013: 1 ), jadi mengacu pada pengertian tersebut, pembelian adalah sebuah aktifitas transaksi yang tujuannya adalah untuk pemenuhan kebutuhan maupun kepentingan yang kita harapkan, hal tersebut ditandai dengan masuknya barang-barang tersebut sebelum nantinya akan kita ambil manfaat dari barangbarang tersebut, ataupun sebuah aktifitas mengeluarkan uang yang kita miliki guna untuk membeli beberapa produk tertentu yang nantinya juga akan kita jual ke konsumen yang lainnya.

Pembelian adalah sebuah perusahaan dagang, pembelian meliputi pembelian aktiva produktif, pembelian barang dagangan serta pembelian barang dan jasa lain dalam rangka kegiatan usaha (Hariyanto, 2016:152).

\section{A. Metode Penelitian}

Peneliti di sini menggunakan pendekatan kualitatif. Pendekatan kualitatif adalah suatu pendekatan yang berdasarkan pada latar alamiah atau naturalis, seperti yang pernah dikemukakan oleh Bogdan dan Taylor (dalam Moleong, 2017: 4) pendekatan kualitatif adalah prosedur penelitian yang menghasilkan data atau bukti observasi. Artinya pendekatan kulitatif itu adalah sebuah pendekatan yang 
menampilkan bukti real yang ada dalam lapangan terjadinya penelitian tersebut. Sedangkan penelitian deskriptif sendiri ialah suatu bentuk paparan secara mendetail sebagai gambaran dari suatu objek yang disajikan atau dibicarakan. Merujuk dari pengertian-pengertian tersebut, maka bisa dikatakan bahwa pendekatan deskriptif kualitatif ialah pendekatan penelitian yang hasilnya berupa prosedur kata-kata tertulis atau lisan dari orang-orang dan perilaku yang diamati guna pengambilan data. Hal yang diamati bisa berupa banyak hal, seperti konteks tuturan, lingkungan, tingkah laku dan suatu kejadian sehingga terbentuklah suatu hal yang utuh.

Data yang digunakan peneliti ialah memaparkan tentang bentuk dan arti yang terkandung di dalam tindak tutur yang diucapkan oleh penjual dan pembeli di pasar Sumberayu Muncar Banyuwangi. Bahan kajian penelitian ini berupa paparan ucapan tindak tutur yang diucapkan oleh penjual dan pembeli di pasar Sumberayu Muncar Banyuwangi. Analisis data dipilih dan dipilah kira-kira mana yang penting lalu dipelajari dan akhirnya baru ditarik sebuah kesimpulan sehingga dapat diceritakan, ditulis serta diulas kembali agar bermanfaat bagi orang lain. Peneliti dalam mengumpulkan data penelitian menggunakan teknik simak dan teknik catat. Dalam penelitian bahasa, teknik pengumpulan data menggunakan teknik simak sadap dasar.

\section{Hasil}

Pembeli (1) :“ Nduwe janganan opo ae mak ?”( Punya sayuran apa saja bu ?) Penjual (1) :"Yo kui, godong kates enek, seladah enek, tewel enek, kangkung yo enek"( Ya itu, sayuran daun pepaya ada, sayur selada ada, sayur tewel ada, sayur kangkung juga ada)

Pembeli (2) : " Njangan opo yo enake ?”( Masak sayur apa ya yang enak ?)

Penjual (2) : "Halah opo-opo enak, kui lho, kangkunge sueger-seger") Sudahlah, apa saja enak, itu lho, sayur kangkungnya segar-segar )

Pembeli (3):" Halah, yo wes mak,tak njangan kangkung ae karo nggoreng iwak" ( Ya sudah bu, saya mau memasak sayur kangkung saja, sama menggoreng ikan )

Penjual (3): "Iyo, sip kui"( Iya, bagus kalo gitu ) 
Pembeli (4):" Yo wes mak, kangkunge telung unting ae, jangan kangkung ki, setengah kurang enak" ( Ya sudah bu, sayur kangkungnya tiga ikat saja, memasak sayur kangkung itu, setengah kurang enak)

Penjual (4) : “ Hahaha, iyo”( Hahaha, iya iya)

\section{A. Percakapan Kedua ( Antara Penjual Nasi Ampok dan Seorang Pembeli )}

Penjual (1) : “Yu, ampok yo !?”( Mbak, nasi ampok ya!? )

Pembeli (1) :" Iyo, ho.o wes, buntelane loro ae "( Iya, iya deh, bungkusannya dua saja )

Penjual (2) :"Oke, tapi sek, tak buntelne waane Buk Tini”

( Oke, tapi sebentar, saya masih membungkuskan punyanya Bu Tini )

Pembeli (2) : "Yo ndang lak no, aku ndang openono mari kui, aku selak kawanen"( Ya cepat kalau begitu, cepat perhatika saya setelah itu, keburu kesiangan saya nanti )

Penjual (3) : "Iyo, amu tak openi mari iki "( Iya, kamu saya perhatikan setelah ini )

\section{B. Percakapan Ketiga ( Antara Penjual Jajanan Dadar Gulung dan Gorengan Weci dengan Seorang Pembeli )}

Pembeli (1) :“Mbak nduwe jajan opo ?”( Mbak, punya jajanan apa? )

Penjual (1) : : "Kowe golek opo bib ?”( Kamu cari apa bib ?)

Pembeli (2) : "Mboh yo, aku pingin mangan opo iki, wetengku louwe"( Tidak tahu ya, saya ingin makan apa, perutku lapar sekali)

Penjual (2): "Nyoh, iki lho, tukuo weci ae"( Ini, ini lho, belilah weci (gorengan) saja )

Pembeli (3) : “Ndelok, heleh moh, weci keple ae kon mangan” ( Lihat, tidak mau,weci (gorengan) sudah kayak gitu kok disuruh makan)

Penjual (3) : "Heeeh, ojo kurang ajar kowe, tak ajar kene"( Heeeh, jangan keterlaluan kamu, saya hajar nanti )

Pemb eli (4) : "Yo wes, aku tak mangan dadar gulunge ae"

( Ya sudah, saya mau makan jajanan dadar gulung saja )

Penjual (4): “Nyoh ”( Ini ) 


\section{Percakapan Keempat (Antara Penjual Gula Merah dan Seorang Pembeli )}

Pembeli (1) : “Yoo, gulone kok uayu”( Waah, gulanya kok cantik)

Penjual (1) : "Nggeh, gulone uayu-ayu niki ”( Iya, gulanya cantik-cantik ini )

Pembeli (2): "Sekilone piro ?”( Satu kilonya berapa? )

Penjual (2): "Limo las ewu bulek"( Lima belas ribu bu )

Pembeli (3): “Empat belas ra oleh ?”( Empat belas apa tidak boleh ?)

Penjual (3): "Ngapuntene, mboten angsal bulek"( Maaf, tidak boleh bu ) Pembeli

(4): “Empat belas yo, aku jaluk sekilo blek”( Empat belas ya, saya minta satu kilo langsung )

Penjual (4) :"Kiloane mboten wonten bulek, entene nggeh bungkusan seprapatan niku"

( Kiloannya tidak ada bu, adanya ya bungkusan seperempatan itu )

Pembeli (5) : "Yoalah, yo wes nyo, sekilo ae"( Haduh, ya sudah ini, satu kilo saja )

Penjual (5) : : "Nggeh bulek, niki "( Iya bu, ini )

\section{Percakapan Kelima ( Antara Penjual Roti Goreng dan Seorang Pembeli )}

Pembeli (1) : "Iki roti gorenge piroan ?"( Ini roti gorengnya berapaan? )

Penjual (1) :"Petang ewuan bulek”( Empat ribuan bu )

Pembeli (2) : “Telu setengah gak oleh ?”( Tiga setengah tidak boleh ? ) Penjual

(2) : "Mboten towo niku, bakul nggeh sak monten"( Tidak menawar itu, penjual juga segitu )

Pembeli (3) : "Owh yo wes, iki sitok ae”( Owh ya sudah, ini satu saja)

Penjual (3) : "Nggeh, nopo maleh ?"( Iya, apa lagi ?)

Pembeli (4) : "Wes kui thok ae"( Sudah itu saja )

\section{E. Pembahasan a. Tindak Tutur Lokusi Percakapan Pertama}

Tindak tutur lokusi terdapat pada tuturanpenjual (1) dan pembeli (1), (2), (3). Tuturan-tuturan yang tersebut, tidaklah mempunyai pengaruh ataupun efek apapun terhadap lawan tutur, artinya tuturan yang dituturkan oleh pembeli dan penjual nomor-nomor tersebut hanyalah sebatas menuturkan sebuah kalimat saja. Ini sesuai dengan pendapat Austin yang menyatakan bahwa lokusi hanyalah 
menuturkan sesuatu, menyampaikan informasi, berbicara, menanyakan, dan lainlain (Austin, 1962, p. 108) (dalam Akhmad Saifudin, 2019: 5 ).

Tuturan-tuturan tersebut, hanyalah sebatas sebagai keterangan dan hanya difungsikan untuk keberlangsungan komunikasi yang dilakukan antara penjual dan pembeli. Hal ini selaras dengan pendapat Sadock, $(1974$, p. 8) yang menyebutkan bahwa tindak lokusi sebagai "tindak yang dilakukan untuk berkomunikasi" dan lebih lanjut lagi, Habermas (1998, p. 122) berpendapat bahwa lokusi adalah tindak menyatakan keadaan sesuatu. Pada intinya dapat dikatakan bahwa mengatakan sesuatu adalah melakukan tindak lokusi sebagaimana tuturan-tuturan yang ada terdapat pada nomor-nomor di atas.

\section{b. Tindak Tutur Ilokusi Percakapan Pertama}

Tindak ilokusi pada percakapan pertama di atas, terdapat pada tuturan pembeli (4), tindak tutur ini termasuk dalam tindak tutur ilokusi direktif. Tindak tutur ilokusi direktif adalah tuturan yang dimaksudkan agar si mitra tutur melakukan tindakan sesuai tuturan, misalnya, memesan, memerintah, memohon, menasihati, dan merekomendasi. Dalam ungkapan yang dituturkan, maksud sebenarnya adalah si pembeli memerintah penjual untuk mengambilkan dan membungkuskan sayur kangkung tiga ikat, karena pembeli memang membeli sayur kangkung tiga ikat tersebut.

Tuturan ilokusi dapat mengandung daya tertentu. Melalui tuturan, orang bisa saja menciptakan sesuatu yang baru, dapat membuat orang melakukan sesuatu, mengubah keadaan, dan lain-lain. Hal ini diperkuat dengan pendapat Habermas, (1998) yang mengatakan bahwa tindak ilokusi, yakni tindak melakukan sesuatu berdasarkan apa yang dituturkan. Lebih jauh lagi, Austin (1962, p. 99) mengatakan bahwa tindak tutur ilokusi itu adalah "performance of an act in saying something" atau pelaksanaan suatu tindakan dalam mengatakan sesuatu. Jadi, tuturan yang diucapkan oleh pembeli tersebut, mempunyai daya atau pengaruh, dan kali ini daya yang dihasilkan adalah memerintah penjual untuk segera menyiapkan barang yang ia beli. 


\section{c. Tindak Tutur Perlokusi Percakapan Pertama}

Tindak tutur perlokusi dalam percakapan diatas, terdapat pada tuturan penjual ( 2), (3), (4). Dalam tuturan-tuturan yang diungkapkan tersebut, semuanya hampir memiliki fungsi sama yakni, meyakinkan. Hal ini sesuai dengan pendapat Austin, (1962) yakni tindak perlokusi adalah apa yang kita hasilkan atau capai dengan mengatakan sesuatu seperti meyakinkan, membujuk, menghalangi, mengatakan, mengejutkan atau menyesatkan.

Dalam tuturan penjual (2), penjual meyakinkan pembeli, bahwa sayur kangkung yang ia jual sangat segar-segar, dan ternyata, apa yang dia ucapkan menimbulkan efek yakni, si pembeli mau membeli sayur kangkung yang segarsegar seperti yang ia ucapkan. Adapun dalam tuturan penjual selanjutya, yakni pada (3) dan (4), yakni sama-sama untuk menimbulkan keyakinan yang lebih di hati pembeli terhadap apa yang ia ucapkan.

\section{A. Pembahasan Percakapan Kedua ( Antara Penjual Nasi Ampok dan Seorang Pembeli ) a. Tindak Tutur Lokusi Percakapan Kedua}

Tindak tutur lokusi percakapan kedua terdapat pada tuturan penjual (1), (2) dan pembeli (1). Dari kata-kata tersebut, hanya sebuah ungkapan pertanyaan untuk pembeli mau membeli ampok tidak dan pernyataan bahwa penjual saat itu sedang sibuk untuk membuntalkan nasi ampok milik Bu Tini, sedangkan ungkapan pembeli pada tuturan tersebut hanya sebuah ungkapan persetujuan bahwa ia meminta buntalan ampok dua buntal saja.

\section{b. Tindak Tutur Ilokusi Percakapan Kedua}

Tindak tutur ilokusi percakapan kedua terdapat pada tuturan penjual (3) dan pembeli (2). Dalam tuturan tersebut, si penjual berjanji bahwa ia akan segera melayani dan menyiapkan pesanan tersebut setelah ia selesai menyiapkan pesanan $\mathrm{Bu}$ Tini. Tindak tutur ini termasuk dalam tindak tutur ilokusi berjenis komisif. Tindak tutur ilokusi komisif adalah tindak tutur yang menuntut penuturnya berkomitmen melakukan sesuatu di masa depan. Contohnya adalah berjanji, bersumpah, menolak, mengancam, dan menjamin. Dan tuturan tersebut menuntut si penjual untuk segera membuntalkan pesanan pembeli tersebut setelah pesanan $\mathrm{Bu}$ Tini selesai. 
Sedangkan tuturan si pembeli (2) adalah sebuah kalimat imperatif atau kalimat perintah. Ia memerintahkan kepada penjual untuk segera membungkuskan pesanannya karena ia takut keburu kesiangan nanti. Tuturan tersebut masuk dalam kategori tindak tutur ilokusi yang berjenis direktif.

\section{c. Tindak Tutur Perlokusi Percakapan Kedua}

Tidak ditemukan tindak tutur perlokusi dalam tuturan percakapan kedua tersebut.

B. Pembahasan Percakapan Ketiga ( Antara Penjual Jajanan Dadar Gulung dan Gorengan Weci dengan Seorang Pembeli ) a. Tindak Tutur Lokusi

\section{Percakapan Ketiga}

Tindak tutur lokusi pada percakapan ketiga di atas, terdapat pada tuturan pembeli (1) dan penjual (2),(4). Pada tuturan-tuturan tersebut, berisikan sebuah kalimat pertanyaan dan pernyataan. Pertanyaan tentang jajanan apa yang tersedia dan pernyataan memberikan makanan yang dibeli.

\section{b. Tindak Tutur Ilokusi Percakaan Ketiga}

Tindak tutur ilokusi pada percakapan ketiga di atas terdapat pada tuturan pembeli (2), (4) dan tuturan penjual (2) dan semuanya masuk dalam jenis tindak tutur ilokusi direktif. Dalam tuturan pembeli (2), penutur mengucapkan hal demikian agar si penjual menyiapkan dan memperlihatkan jajanan yang ia jual yang mungkin ia berselera untuk memakannya. Sedangkan dalam tuturan penjual (2), penjual menuturkan hal tersebut, agar si pembeli membeli jajanan yang saat itu sedang ia tawarkan. Sedangkan untuk tuturan pembeli (4), ia termasuk ilokusi karena maksud yang ingin ia sampaikan adalah agar penjual mengambilkan jajanan yang lainnya saja, dibandingkan jajanan gorengan weci yang menurutnya sudah tidak enak.

\section{c. Tindak Tutur Perlokusi Percakapan Ketiga}

Pada percakapan ketiga di atas, tindak tutur perlokusi terdapat pada tuturan pembeli (3) dan penjual (3). Pada tuturan pembeli (3), ia mengucapkan tuturan tersebut, dan kalau kita perhatikan lebih mendalam, ada unsur menghina dagangan si penjual dan hal tersebut menyebabkan perubahan psikologis dalam diri si penjual dan sekaligus ia marah karena dagangannya telah dihina dengan tuturan tersebut. Sedangkan dalam tuturan penjual (3), ia menuturkan dengan kata-kata tersebut 
sebagai pelajaran kepada si pembeli dan agar nantinya secara psikologis si pembeli menjadi takut dan tidak sembarangan lagi dalam bertutur.

\section{Pembahasan Percakapan Keempat (Antara Penjual Gula Merah dan}

\section{Seorang Pembeli ) a. Tindak tutur lokusi percakapan keempat}

Tindak tutur lokusi pada percakapan keempat ini sangat dominan. Tindak tutur tersebut, terdapat pada tuturan penjual (1), (2), ( 3), ( 4 ), (5), dan tuturan pembeli (2), (3), (4). Tuturan-tuturan tersebut hanya sebatas tuturan pertanyaan, pernyataan, penolakan dan lain-lain.

\section{b. Tindak tutur ilokusi percakapan keempat}

Tindak tutur ilokusi percakapan keempat terdapat pada tuturan pembeli (5). Tindak tutur ini berjenis tindak tutur ilokusi direktif. Dalam tuturan tersebut, si pembeli meminta penjual agar segera membungkuskan gula merah satu kilo, sesuai apa yang ia beli.

\section{c. Tindak Tutur Perlokusi Percakapan Keempat}

Tindak tutur perlokusi percakapan keempat terdapat pada tuturan pembeli (1). Pada tuturan tersebut, pembeli tersebut memuji gula merah yang dijual oleh penjual tersebut. Hal ini, menyebabkan rasa senang dalam diri si penjual. Dengan begitu, ia semakin yakin bahwa gula yang ia jual benar-benat disukai oleh pembeli di pasar tersebut.

\section{Pembahasan Percakapan Kelima ( Antara Penjual Roti Goreng dan}

\section{Seorang Pembeli ) a. Tindak Tutur Lokusi Percakapan Kelima}

Tindak tutur lokusi percakapan kelima terdapat pada tuturan penjual (1), (2), (3), dan pembeli (1), (2), (4). Tuturan-tuturan pada nomor-nomor tersebut hanya sebatas sebagai alat untuk keberlangsungan komunikasi tanpa menimbulkan efek ataupun mengandung daya tertentu.

\section{b. Tindak Tutur Ilokusi Percakapan Kelima}

Tindak tutur ilokusi terdapat pada tuturan pembeli (3). Tindak tutur ini berjenis tindak tutur ilokusi direktif. dalam tuturan ini, pembeli memerintahkan kepada penjual agar segera menyiapkan apa yang menjadi pesanannya. 


\section{c. Tindak Tutur Perlokusi Percakapan Kelima}

Dalam percakapan kelima tersebut, tidak ada tindak tutur yang mengandung tuturan perlokusi.

\section{F. Kesimpulan}

Dari pemaparan di atas, diketahui bahwasannya dalam transaksi jual beli antara penjual dan pembeli pastilah tidak bisa terlepas dari proses komunikasi atau tindak tutur, dan dalam memahami setiap tuturan yang diucapkan, kita tidak bisa hanya memerhatikan dari kata-kata yang terujar saja, namun ada hal lain yang juga perlu kita perhatikan, yakni konteks yang terjadi saat itu.

Dalam penelitian yang telah peneliti lakukan di Pasar Desa Sumberayu Kecamatan Muncar selama beberapa waktu, peneliti menemukan 19 bentuk percakapan yang terdiri 86 tindak tutur lokusi, 20 tindak tutur ilokusi, dan 14 tindak tutur perlokusi yang dituturkan antara penjual dan pembeli yang terdiri mulai dari penjual sayuran, penjual buah-bauhan, penjual nasi ampok, penjual jajanan tradisional, penjual kedelai dan lain-lain.

\section{Daftar Pustaka}

Chaer, Abdul. 2010. Kesantunan Berbahasa. Jakarta: Rineka Cipta.

Chaer, Abdul. 2010. Sosiolingiustik: Perkenalan Awal. Jakarta: Rineka Cipta.

Chaer, Abdul dan Agustina, Leonie. 2010. Sisiolingiustik Perkenalan Awal. Jakarta: PT RinekaCipta.

Claudiu-Catalin, M., \& Dorian-Laurentiu, F. 2014. Radical brand extensions and consumer profile - a new perspective on innovation and consumer innovativeness. Procedia-Socialand Behavioral Sciences. 109. 108- 112.

Hariyanto, Dicky. 2016. Rancang Bangun Sistem Informasi Pembelian dan Penjualan Barang Berbasis Website. “Jurnal dari SWABUMI “, ISSN : 2355-990, Vol. IV No. 2: 152-166. 
Hayuningtyas Ratih Yulia. 2015. Rancang Bangun Sistem Informasi Penjualan Tas pada Toko Lokalop. “Jurnal dari Sistem Informasi STMIK antar Bangsa”, ISSN 2089- 8711 Vol. IV NO.2 : 160-167.

Keraf, Gorys. 2001. Komposisi. Nusa Tenggara Timur: Nusa Indah.

Kitab perundang-undangan Republik Indonesia ayat 22 Pasal 5 UU Nomor 8 tahun 199923.

Kushartanti. 2009. Pesona Bahasa Langkah Awal Memahami Sosiolingusitik. Jakarta: Gramedia.

Mega, Mahar, 2013. Manajemen Pemasaran. Yogyakarta: CAPS (Center of Academic Publishing Service).

Moeleong, Lexy. 2017. Metodologi Penelitian Kualitatif. Bandung: PT. Remaja Rosda karya.

Nugroho, Bunafit. 2013. Membuat Aplikasi WEB Penjualan Pembelian dengan PHP, MySQL dan Dreamweaver. Yogyakarta: Penerbit PT.Alif Media.

Parise, S., Guinan, P. J., \& Kafka, R. 2016. Solving the crisis of immediacy: How digital.

technology can transform the customer experience. Business Horizons (2016). RetrievedMarch 4, 2016, from http://dx.doi.org/10.1016/

Rahardi, R. Kuncana. 2009. Pragmatik kesantunan Imperatif Bahasa Indonesia. Jakarta: Erlangga.

Sugiyono. 2011a. Metode Penelitian (Kuantitatif, Kualitatif, dan R\&D). Bandung: ALPABETA CV.

Sugiyono. 2015b. Metode Penelitian Pendidikan (Pendekatan Kuantitatif, Kualitatif, dan $R \& D$ ). Bandung: ALPABETA CV.

Sugiyono. 2016c. Metode penelitian (Kuantitatif, Kualitatif, dan $R \& D$ ) Bandung: ALPABETA CV.

Tarigan, Henry Guntur. 2015. Berbicara Sebagai Suatu Keterampilan Berbahasa. 
Bandung: Angkasa.

Tarigan, Henry Guntur. 2009. Pengajaran Pragmatik. Edisi Revisi. Bandung: Angkasa.

Wijana, I Dewa Putu. 2009. Dasar-Dasar Pragmatik. Yogyakarta: Andi Yogyakarta.

Yule. George. 2004. Pragmatik. Yogykarta: Pustaka Pelajar. 